\title{
The Fragility of the Liberal Peace Export to South Sudan: Formal Education Access as a Basis of a Liberal Peace Project
}

\author{
Ngambouk V. Pemunta ${ }^{1, *}$ and Eno-Akpa R. Nkongho ${ }^{2}$ \\ ${ }^{1}$ Department of Cultural Sciences, Centre for Concurrences in Colonial and Postcolonial studies, Linnaeus \\ University, 35195 Växjö, Sweden \\ ${ }^{2}$ Department of Public Policy, Central European University, Nador utca 9, 1051 Budapest, Hungary; \\ E-Mail: enoakpar@yahoo.com \\ * Corresponding Author: E-Mail: vitalispemunta@gmail.com; Tel.: +46 729469558; Fax: +46 47083217 \\ Submitted: 28 March 2014 | In revised form: 20 June 2014 | Accepted: 1 July 2014 | \\ Published: 20 November 2014
}

\begin{abstract}
This study examines the disjuncture between the policy transposition of the Liberal Peace Project (LPP) in South Sudan from the country's local context. It underlines how deep rooted historical exclusion from social welfare services reinforces political exclusion and exacerbates poor civic engagement among different ethnicities in the country causing a constant relapse to violence. The study combines a qualitative review of data from Afrobarometer, the National Democratic Institute, international NGOs, and South Sudan's government reports with indepth interviews and participants' observation. The research finds that restricted access to formal education alongside the conservative and orthodox approaches to peacebuilding, which broadly focus on centralised urban political institutions and exclude diverse local needs and preferences, limit citizenship participation to elections and preclude an equitable social order in South Sudan, establishing a continuum of fragile authoritarian peace, institutional peace and constitutional peace. In an emancipatory approach, the study proposes a framework that prioritizes an extended access to primary and post-primary vocational education as a more credible establishment for sustainable civil peace in the country. The LPP by the international community needs to be tailored to enhance the political will of the South Sudan government to extend free primary education access, incentivize primary education with school feeding programmes and to invigorate vocational training curricula. These will yield civil peace dividends, which avert South Sudan's structural source of relapse into violence with sustainable disincentives. Apart from women's empowerment through education and in all spheres of life, the government needs to ensure sustainability by guaranteeing a sustainable future for the present and for returning refugees by reducing the effects of climate change so as to cope with the increasing pressure on natural resources.
\end{abstract}

Keywords: conflict; formal education; liberal peace; peacebuilding; post-conflict settlement; South Sudan 


\section{Introduction}

The world's newest nation-the Republic of South Sudan (RSS), is once again in prolonged international media coverage, and has been since 15 December 2013. Characteristic of her history, the potracted conflict over socio-political and economic marginalisation by the Republic of Sudan of then South Sudan has resurfaced in the RSS, ending not just the euphoria of its independence from the Republic of Sudan on July 9, 2011 but also, crippling hopes for a politically inclusive state with an equitable social order. In retrospect, one is obliged to wonder whether the 2005 Comprehensive Peace Agreement (CPA), ending decades of civil conflict against the people of South Sudan and subsequent peacebuilding attempts in the post independence federal, presidential democratic RSS, are apt enough to yield sustainable civil peace. Peacebuilding or the Liberal Peace Project connotes the processes aimed at reviving the state's capacity to identify, support and strengthen her socio-political and economic structures in view of averting structural factors that cause or nurture a relapse into violent conflict $[1,2]$. However, the LPP in RSS has evidently failed and the country is back to war, echoing a political power tussle with ethnic undertones opposing the majority Dinka of president Silva Kiir and his ex-deputy Riek Machar from the Nuer ethnicity. Empirical evidence suggests a concentration of civil wars in countries with little education like the RSS. Conversely, in a country with a higher proportion of its youth in school, the risk of conflict is significantly reduced [3-6].

\section{Aim and Method}

This paper examines the mismatch between peacebuilding and locally felt needs of conflict resulting from the LPP in the RSS. The crux of the argument is that the lack of formal education opportunities constitutes a structural source of relapse to conflict in South Sudan. Consequently, the consolidation of democratic institutions, modelled on the conservative and orthodox approaches to peacebuilding that characterize the current practices of the LPP in the country does not target the root causes of violence and its recurrence. The paper concludes that the prioritization and provisioning of formal education opportunities is justifiable and would serve to attain the LPP objectives of civil peace. The paper underlines the fact that though the emancipatory approach of the LPP-the bedrock of international peacebuilding initiatives is highly considered of theoretical and impracticable value [7], it could operationalize the approach through institutions of primary and post-primary vocational education. The study highlights the need to accomplish meaningful social, political and economic inclusion of a population easily induced to violence in South Sudan's peacebuilding process through increased access to primary education and post primary vocational training as an urgent policy implementation option that would disincentivize recourse to violence and rather induce durable or civil peace.

The study made use of bottom-up (felt needs) and a top-down methods that underpin the emancipatory approach of the LPP. It involves substantial, qualitative, desk research that reviewed reports, surveys and documents of peacebuilding stakeholders (civil society organizations, bilateral aid donors, multilateral peace agencies) and the national government of South Sudan. Individual in-depth interviews and participant observation were also used to abduce information from stakeholders.

\section{Background: Agitation and Resistance from Social and Political Exclusion}

Sudan's history is characterized by a specter of unending civil wars that has significantly affected Southern Sudan, accounting for the relapse to conflict in the new country. Sudan, from which South Sudan gained independence suffered two major civil strifes between 1955 and 1972 and from 1982 to present. This 'long history of political vulnerability and exclusion' ([8] p. 1) disproportionately affected Southern Sudan. During the Anglo-Egyptian condominium (1899-1934) the British imperial government, and later the ruling northern elites, used education as a tool for the perpetuation of socioeconomic and political marginalization of both majority rural communities and Southern Sudan in particular. The British 'Northern policy' encouraged and perpetuated the socio-economic exclusion and marginalization of Sudan at the detriment of the then Southern Sudan. They modernized the economy and infrastructure of the north while Christian missionaries provided the much needed 'moral guidance' rather than economic development in the Southern Sudan. This 'Northern policy' did set the stage for political vulnerability and exclusion of Southern Sudanese.

In a glimpse of recognition of the problems of Southern Sudan in the time of the Anglo-Egyptian Condominium, Britain passed the 'Closed District Order' of 1922. This Order was an anti-Islamic policy meant to curtail northern dominance and slave raids in Southern Sudan. Within this policy framework, vernacular languages in Southern Sudan became the language of instruction while English was the official language. Arabic was banned from school and government offices in Southern Sudan. Although these policies were 'based on indigenous cultural values and Christian cultural norms', and instilled a sense of identity in Southern Sudanese, the real aim was to link Sudan with East Africa for easy administration as part of British indirect rule system.

However, these policies woefully failed to spike socio-economic development, but instead widened the existing inequities between the North and South. In the 1940s, South Sudan's educational infrastructure was comprised of a limited number of missionary 
schools, few elementary government schools, one teacher training centre, one commercial school and one senior secondary school ([8] p. 2, [9] p. 3,[10] p. 86). Worse still, the British represented the indigenous population as lazy and unenthusiastic in improving their socio-economic wellbeing ([11] p. 32). However, at the end of World War II the unity of Sudan took greater impetus due to pressure from Egypt and the northern elites, causing the British to address the need to accelerate economic and educational development so as to put Northern and Southern Sudan at par ([10] p. 88).

This explains why in 1957, the Government of Sudan took over mission schools in South Sudan, and in 1962 expelled Christian missionaries from the South for allegedly inciting South Sudanese against the Arabization and subsequent Islamization of schools. This suggests that one key factor for anti-government agitation is the adoption of policies that exclude South Sudanese from formal education opportunities, a situation that also reflects a quality of education far removed from the context of South Sudan. This exclusion of South Sudanese from formal educational opportunities further explains how lack of formal education affected the ability of South Sudanese to participate in government beneficially, or to yield the positive externalities of an educated environment which would generally have led to improved welfare of the population in question [4].

The exclusion of Southern Sudanese from formal education severely curtailed their access to schoolslegitimized their cultural suppression and social exclusion. Furthermore, it lowered the retention rates of Southern Sudanese at school, implying their exclusion from skilled professions, from public service institutions and political participation $[4,12]$. This lends credence to the fact that in civil strife endemic areas-(the lack of) education generates significant negative externalities. Independence was eventually brokered with the northern elites, who became the new colonial power. Thereafter, Sudan slipped into a 17 year civil war that ended in 1972.

In the post-independence era-the northern Sudanese elites and the Sudan central government effectively used the educational apartheid paradigm as a political tool, underpinned by Arabo-Islamism as the cornerstone of national unity. The educational system was tacitly used to undermine the religious and cultural diversity of Sudan since recognition of diversity was perceived as incompatible with the raciocultural equity of the southern part to the northern part of the country. Islamization was used as a tool of civilization with the aim of erasing "the pagan patrimony". This explains why Arabic came to replace English as the language of instruction leading to intense widening of the gap between north and south. Additionally, apart from rewriting the history, Northern Sudanese historians simultaneously erased-"the Sudanese indigenous history" while the culture and tradition of the latter "have never been imparted in education policy since the dawn of independence in $1956 "$ ([8] p. 2). During the four years preceding Sudan's independence, less than $8 \%$ of children in the South were in school, while the share of girls was almost zero, compared to $20 \%$ of girls in the North who were enrolled in all primary streams ([8] pp. 34). After self-autonomy in 1982, the Sudan central government failed to provide adequate resources and social and economic services further incapacitating Southern Sudanese. With an estimated population of 20 million, primary school enrolment was $40 \%$ in Northern Sudan, while it was less than $12 \%$ in Southern Sudan. The 'Southern policy' of forging a Sudanese identity for both the northen and southern parts, which was based on the Arab-Islamic paradigm with the educational system as the basis, led to frustration and Southern Sudanese took up arms in 1982 agitating for independence with the hope of establishing a more equitable and inclusive society.

At independence in 2011, the RSS was extremely fragile due to decades of conflict with the Republic of Sudan, partly over oil wealth. Prior to this date, since independence in 1956 Sudan has been engulfed in two major civil wars (1955-72, and 1982-present). The country's new leadership is comprised largely of former rebels who had often fought each other. Most notably, Silva Kiir and his ex-deputy Riek Macher and others split away from the main rebel group-the Sudan People's Liberation Movement/Army (SPLM/A) in 1991. The independence of the RSS has since been only a lull as the rift between the protagonists Macher and Kiir gets deeper and-intractable, inducing sociopolitical and economic exclusion along ethnic lines, commemorating - the political fractures that triggered the RSS's fight for independence. The civil strife in the RSS now exacerbates deep-seated ethnic animosities and tensions. At independence the RSS was dismally bereft of basic social services and infrastructure: the outcome of decades of civil strife and decades of neglect despite its huge oil and mineral wealth. Corruption and nepotism orchestrated on regional and ethnic lines remained rampant and widespread [13].

Although precluded from the United Nation's Development Programme's (UNDP) Human Development Index (HDI) due to data constraints, the 2006 Household Health Survey [14] and the 2009 National Household Baseline Survey [15] provide some insights into human development trends in the country. In 2009 , infant mortality rates were 102 out of 1 '000 live births, a slight improvement from 131 in 2008 and lower than rates for Burundi (106). In the same period, under-five mortality rates dropped from 381 to 135 per 1'000 live births. These improvements were the result of a slight increment in public expenditure for primary health care and the temporary return of peace following the signing of the CPA. This notwithstanding, South Sudan topped the global maternal mortality chart in 2009 with 2'054 per 100'000 live births, and the 
lowest life expectancy in East Africa at 42 years. Education and formal literacy levels remained extremely low: only $27 \%$ of children over 15 years old were considered literate (compared to $77 \%$ in Rwanda, $73 \%$ in Uganda, $70 \%$ in Tanzania, $62 \%$ in Kenya and $47 \%$ in Burundi). While the net school enrolment rate was merely $48 \%$, only $37 \%$ of the total population above six years old had attended school. These trends are attributable to long periods of internecine strife during which there was an acute shortfall in the delivery of public goods and services as well as to the accompanying insecurity. Low literacy is further compounded by poor access rates, inadequate educational infrastructure and the potential increase in demand for schooling with the return of refugees. The net intake rate to the first year of primary school stood at $14.6 \%$ [16]. The pupil/teacher ratio was 52:1, the pupil classroom ratio was 129 children per classroom and the net enrolment rate stood at $48 \%$ ([17] p. 17). South Sudan ranks at the bottom of all human development indicators: 8 out of 10 persons live on less than $\$ 1.63$ a day; a net primary education enrolment of $46 \%$; a qualified teacher to pupil ratio of $1: 117$ and a literacy rate of $27 \%$ [18]. Estimates of the female illiteracy rate exceed $80 \%$, it has the the world's highest maternal mortality rate, less than 100 kilometres of paved road, suffers from the risk of increased violence and harm to civilian population and permanent humanitarian suffering [18] given the ongoing political turmoil in the country. About 38'000 children under 18 years of age have reportedly been conscripted into the army, forced labour or slavery over the past 15 years in Southern Sudan. These abductions have eventuated into a demographic imbalance: a drastic decrease in the number of males in the 20-39 age bracket when compared to females ([20] p. 1). The country is bedecked by lack of basic services, poor harvests, rising food prices, lack of jobs, lack of governance skills in public officials, corruption/nepotism in public institutions and political domination [18]. The country's economy is unhealthily dependent on oil that guarantees $98 \%$ of GDP from which $35 \%$ of revenue is spent on state security and security sector reforms and $7 \%$ and $4 \%$ respectively are devoted to health and education [21]. Education in South Sudan is facing several challenges: poor coordination of education services, lack of national goals, policies and standards for education, increased insecurity, frequent displacement and the constant recruitment of male children by warring factions as 'child soldiers'.

Compounding this situation and further threatening the ephemeral peace with human security implications is climate change that tends to exacerbate the degradation of the environment-and lead to resource use conflicts and pose both direct and indirect threats to food security. In South Sudan, the duration and timing of rain is becoming erratic. Rainy seasons are increasingly not only delayed but also shortening at a rate of $30-40 \%$ [22]. As a result, the incidence of drought and flooding are not only inevitable but are increasingly becoming more frequent- temperatures are rising in winter, often with disastrous consequences for the population and the environment. These changing rainfall patterns spell doom for rural farmers in particular and the population at large. Further consequences of climate change include, but are not limited to: cholera outbreaks, poor crop yields and late harvests, as well as severe crop losses. The drying of permanent rivers is resulting in seasonal rivers, reduction of water tables in boreholes, delays and shortening of rainy seasons. Simultaneously, some regions are generally receiving less rain, and the amount of water is dropping, leading to drought. The reduction in rainfall has turned millions of hectares of already marginal semi-desert grazing land into desert. People have been forced to migrate and added significant stress on the livelihoods of pastoral societies as pastoralists and agriculturalists are at each other's throats for access to scare natural resources. On the other hand, some areas have more intense rain events, driven by climate change, which contributes to more run-off and floods, threatening food security and settlements, and leading to diseases such as cholera. The Sahara Desert is also expanding southwards [23]. The change in rainfall patterns has led to food insecurity, vast migrations and loss of animals, especially cattle. Crops and livestock are threatened in a country where about $80 \%$ of the population are cattle rearers leading a pastoralist lifestyle. There is also intense competition for natural resources which are increasingly scarce due to global warming, leading to rapid deforestation, land grabbing, and tenure insecurity due to resettlement of people returning to South Sudan after the war, as well as high rates of land privatization. The vicious cycle of multiple stresses "endemic poverty, ecosystem degradation, complex disasters and conflicts, and limited access to capital markets, infrastructure and technology have all weakened people's ability to adapt to changes in climate" ([23] p. 3, [24] p. 2).

Deforestation is accelerating due to wood being collected for fuel, charcoal production, livestock, agriculture, bricks, and the collection of construction materials. There is also intense competition for portable water between people and livestock, as well as habitat degradation for livestock and wild life due to vegetation degradation and desertification (most accentuated in the North and Southeast). It has been estimated that in the Upper Nile province, each removed tree results in the deforestation of 0.03 ha and that the annual use of charcoal of one family accounts for 2.6 ha of deforestation in that area. Furthermore, huge quantities of charcoal (60'000 bags) representing 2'700 hectares of deforested land are also exported from the Renk County in Upper Nile to Sudan ([22] p. 4, [37,38]). A study conducted by the International Food Policy Research Institute (IFPRI) found that temperature anomalies significantly affect the risk of conflict. Through the prism of the 
local weather in South and North Sudan between 1997 and 2009, the organization maintains that, in the future, the risk of violent conflict caused by global warming is expected to magnify in a range of $21-30 \%$ under a median scenario, while factoring in uncertainties in both the climate projection and the estimate of the response of violence to temperature variations. The report further underlines that extreme temperature shocks are found to strongly affect the livelihood of violence as well, but the predictive power is hindered by substantial uncertainty $[22,23,25]$.

The latest Integrated Food Security Phase Classification (IPC) analysis conducted in April and May 2014 in South Sudan indicates that a conjuncture between conflicts, displacement, destroyed markets and disrupted livelihoods has led to the deterioration of food security since the outbreak of conflict in 2013. Most people in the three most conflict-affected states of Unity, Upper Nile and Jonglei scored 4 on the IPC scale of 5 showing an alarming increase in the number of people in the IPC Food Security phase. Some 1.3 million of the country's 11.5 million people are experiencing emergency levels of food insecurity. Additionally, 2.4 million people are in the IPC Food Crisis Phase (scoring 3 in the IPC scale of 5) suggesting that they need urgent assistance [25]. These figures indicate that more than one-third of South Sudanese are facing exceptional levels of food insecurity. These figures further suggest a conjuncture between widespread hunger, and growing malnutrition, diseases, livelihood losses and the likelihood of death.

The situation is likely to deteriorate as the food security crisis spreads to previously unaffected areas, except farmers are able to plant their fields, fishing communities can freely have access to rivers and water ways and herders can migrate between grazing areas. Food secure communities are feeling the strain of conflict as they experience the burden of hosting internally displaced people. This has engendered conflict over scarce resources, leading to accentuated environmental degradation $[22,23,25]$. The lack of access roads makes intervention by humanitarian agencies challenging, as most displaced communities are increasingly being cut off by a vicious cycle between rains that bring seasonal flooding and inadequate access due to conflict. A cholera outbreak has already claimed the lives of 23 people in Juba and forced more than 670 others to seek treatment [26].

The surging and thriving of conflict is correlated with low HDI and human insecurity. In the RSS, human development and conflict are intertwined: "War and violence pervade all aspects of human development". The impacts may be direct, when people are killed or injured. "Or they may be more indirect conditions of insecurity blocking farmers from working their lands, women from leaving their homes for fear of sexual violence or children from attending schools. The absence of peace constrains the choices and freedoms of people. Peace provides the foundation for life, human development and human freedom". Human security argues for placing the human individual at the centre of security attention, rather than focusing on the rise or fall of state power alone. The risks stemming from multiple threats to the human individual and communities in (South) Sudan emerge as a key means to understand and assess security challenges, from violent conflict to lack of adequate drinking water or access to medicines to manage diseases. "Human security effectively serves as a mirror of human development: while human development as an approach focuses on expanding the real freedoms people enjoy, human security ensures the protection of these freedoms" ([27] pp. 18-19).

The human security framework is underpinned by the premise that high human development can help generate conditions for peacebuilding by removing economic and social injustice as a cause for grievance. And that peace in turn can help to establish human security conditions that further human development achievements. This reinforcing relationship can break the vicious cycle of low human development and conflict experienced in Sudan ([27] p. 19). Low levels of human development and high levels of poverty and inequality act as drivers of conflict. The lack of schools, or poor education quality with thwarted aspirations and high levels of unemployment can create a volatile pool of disaffected young people. The population of South Sudan is estimated at 8.3 million: 4 million (48.2\%) are female and 4.3 million (51.8\%) are male. It should be noted that a large proportion of the population of South Sudan are still refugees living in other countries. The population was estimated to have expanded to 10.6 million by July 2012 due to the return of refugees [17]. There is a high concentration of the population in rural areas. The annual population growth rate stands at $2.9 \%$ with a low population density of 13 people per square kilometre. About $72 \%$ of the population is aged below 30 years, $51 \%$ under 18 and $30 \%$ under 10 . Most South Sudanese people are young, live in rural areas. The CPA (2005) led to the temporal restoration of peace, saw improved development indicators, the return of refugees and improvement in fertility and life expectancy. This has resulted in increased demand for extra resources to deliver public goods, especially in rural areas ([17] p. 8) where poverty is a lived reality.

More than half of the population (50.6\%) is considered poor. However, poverty is gendered with women accounting for $51.6 \%$ of those living below the national poverty line of US\$28 per month. Poverty is accentuated in rural areas, home to nine out of ten poor people. This is significant, given that $24.4 \%$ of urban against $55.4 \%$ of rural people are considered poor. The incidence of poverty varies across states: three quarters of poor people are found in Northern Bahr El Ghazal whereas, only a quarter of the population in Upper Nile are considered poor ([17] p. 9). The geography of poverty in South Sudan is further 
characterized by high inequalities in incomes. A huge gap exists in consumption between the poor and nonpoor. The Gini-coefficient (a benchmark used to estimate inequality) puts the gap between the poor and non-poor at 45.5. Collaborating this estimate, the 2009 National Household Baseline Survey showed that consumption per person in the uppermost 90th deciles of the population was more than ten times that in the lowermost 10 deciles and that on average, poor people consumed about $25 \%$ more than the non-poor [14]. The existence of significant development disparities between urban and rural areas is driving rural-urban migration and growth in the informal sector, thereby depriving rural areas of productive human capital and exacerbating poverty.

Nevertheless, poverty and low human development achievements are only partial causes for insecurity. Colonial roots and environmental degradation also play important roles. "Sudan might be the first site of violence induced by climate change. The movement of the Sahara desert up to 150 kilometres in some locations poses a severe threat to migratory groups or settled population over dwindling resources. This makes environmental stewardship a central concern for peace and human development in Sudan" ([28] p. 20).

\section{Education and the Liberal Peace Project}

Critical scholars on peacebuilding are unanimous on the need for social justice and welfare inclusion to the LPP as a desirable emancipatory approach to achieve sustainable civil peace in post war environments [7,2932]. This is because post Cold War civil conflicts are multidimensional. They involve tensions around ethnic identity; the failure of legitimate or effective governance, discriminatory politics, widespread poverty and socio-economic inequality between constituent groups, war economies thriving on the capture and trade of natural resources, and easy access to small arms and light weapons [33-34]. As a consequence, international efforts at peace operations have evolved through four generations: Peacemaking, Peacekeeping, International Statebuilding into peacebuilding or the Liberal Peace Project-LPP [2]. Boutros Boutros-Ghali first injected the concept of Peacebuilding into the UN system in his An Agenda for Peace, raising the need for multilateral international interventions in conflict zones to effect policy reforms beyond monitoring disarmaments and supervising the implementation of peace agreements among warring parties to effecting post conflict peacebuilding [1].

From the 1990s, multilateral peacebuilding actors assumed that "there is a universally agreed normative and cultural basis for the liberal peace (model) and that interventionary practices derived from this will be properly supported by all actors" ([35] p. 111). Subsequently, the international policy of post war reconstruction emphasized peace agreements, security sector reform, democratic institutions (constitution building, elections, rule of law institutions, human rights enforcement) and the installation of a free market economic model in post-settlement Peacebuilding $[29,36]$. Unfortunately, about half of the peacebuilding missions failed in about five years of liberal peace import, as evidenced by recurring violence, and thereby raising policy failure alarms [37], raising a need for the LPP to move from institutional peace (non-violent status quo based on anchoring post conflict states within the normative and legal contexts of transnational organizations such as the UN) and constitutional peace (resting upon the establishment of democratic values and free trade in post conflict states) to civil peacefounded on averting violence through immediate post conflict state response to citizen advocacy and mobilization for welfare needs and social justice [7].

Both its critics and its advocates argue that the LPP paradigm is in crisis because it prioritizes building government capacity (which tends to guarantee institutional and constitutional peace) that will deliver inclusive, social welfare services only in the future over more immediate capacity building and instant service delivery, which brings about civil peace $[29,7,31]$. Critics argue that liberal peace missions have largely recreated states (Afghanistan, Somalia, Liberia, Angola, Haiti and even Cambodia) with weak domestic governance incapable of providing public goods, poor human rights records and contexts where the rule of law is increasingly questionable and where conditions for a relapse to armed violence are imminent $[37,38]$. Furthermore, lack of local ownership [36], close ended time frames of liberal peace mission that conceive of peace as a state of affairs rather than a dynamic process and lack of strategic coordination and inadequate attention to domestic tensions and local context $[29,38]$ have been invoked as the causes of the failure of liberal peace. As a concept, the LPP connotes provision of post conflict humanitarian assistance; political, social and economic reconstruction; security sector reform and international statebuilding. The LPP is underpinned by conservative, orthodox and emancipatory theories [7] but the practical methods for achieving sustainable peace or civil peace in post conflict countries like South Sudan are elusive $[32,7]$.

Robin Luckham, a key advocate of the emancipatory approach to peacebuilding emphasises the relationship between democracy, security and development as being the cornerstone of global liberal governance. This relationship, he concedes, should inform the conceptualization of the fourth generation peace interventions [39]. Peacebuilding is thus-reconstructed through local and international agencies, and their mediation, to include institutions, rights, needs, culture, and custom, from security, political, economic, social welfare and justice perspectives dictated by the internal context of the mission [40]. Commenting on the fragility of the LPP in South Sudan, Ylonen suggests that there is need for the peacebuilding interventions and the South Sudan government to create political, 
economic and social institutions that are inclusive as well as providing wider access to welfare services [32]. However, the practical ways to deliver civil peace through this emancipatory approach that guarantee structures preventing a relapse into conflict have remained elusive.

Since the Comprehensive Peace Agreement (CPA) to the independence (2011) and post independence of South Sudan, peacebuilding has suffered from a lack of local reception, a lack of durable participatory governance and a frequent relapse into violent conflict [32]. It has been argued that liberal peacebuilding in South Sudan is detached from the internal reality thereby making stability in the country fragile. Among other things, "tangible development progress, such as (the) building of hospitals or gaining access to quality education, are seen as vital in establishing peace and this realization needs to be at the heart of peacebuilding activities" ([30] p. 10). Formal education-the medium for imparting pedagogic instruction, shared values, good attitudes and behaviours [41] is a social welfare institution, a social justice mechanism for marginalized and disgruntled groups and a locally acclaimed means for the emancipatory approach to the LPP to take root in South Sudan. In countries emerging from wars, a well designed formal education curriculum may ease psychological violence (fear and hatred) in the minds of survivors and victors, helping them to desist from being fanatics, or supporting ideology that legitimize structural violence [42]. It must be stated that formal education, in post war settlement countries may make or mar new publics either creating "a conglomerate of self indulgent consumers; ... (and) angry soulless, directionless, hopeless masses; indifferent,confused citizens; or a public imbued with confidence, sense of purpose...respect for tolerance" ([43] p. 18). This implies that the formal education curricula in peace reconstruction countries like the RSS should foster positive social relations, multiethnic integration and community development.

A 1994 review of 98 country cases from 1960-1990 by George Psacharopoulos shows that the private and social rates of returns from primary education stand at $20.8 \%$ and $18.2 \%$ in annual returns of the initial costs, reducing poverty and enhancing social welfare for countries that opt for policies that broaden access to primary education $[44,5]$. Moreover, post-primary vocational training would yield social benefits (positive externalities such as modernization and social integration of ethnic groups, improved civic engagement and improved standards of living). In addition to private gains (e.g. jobs, greater income, savings, investments), formal vocational training will help broaden the government revenue source and sustain peace dividends and the production of public goods for example, security and basic services [6]. We argue that the private returns of education can be easily measured in quantitative terms (e.g. in income or contribution of taxes coming from such income to government revenue or jobs that are created because of training and its impact on Gross Domestic Product (GDP). The Social returns of education are qualitative in nature and it is common knowledge that for the more literate populations of the North, it might be less easy to persuade citizens into patronage politics. Such citizens tend more than their uneducated counterparts to issues of the day and engage into political and civil life in more beneficial ways.

However, in its 2011-2013 Development Plan, the Government of South Sudan recognised that its education and health indicators are among the lowest in the world, reflecting the impact of protracted conflict and limited provision of social services. Only $27 \%$ of the adult population is literate and less than half of all primary-school-age-children are in school ( $51 \%$ of boys and $37 \%$ of girls). The ratio of qualified teachers to pupils stands at 1:117 [21]. Yet education is positioned with regard to the budget as the last priority area in its development plan. Apart from the fact that external actors (foreign states and intergovernmental organizations) commit inadequate funding and capacity building to revive access to quality education in South Sudan-6\% of 2009 donor funding $[45,18]$, the new deal for measuring progress in peacebuilding excludes education and only focuses on legitimate politics, security, legal justice, economic foundation and state revenues [45].

In fact, most international agencies "opted not to support and facilitate the creation of a conducive education policy environment but rather to work in isolation under the pretext of supporting the community-based education initiatives". Also, the donor communities have different perspectives to education in conflict areas. While the United States Agency for International Development (USAID) supports education in South Sudan, other donors have taken a rather lukewarm attitude towards education ([8] $\mathrm{p}$. 11). This is the case even when education has been recognised during civil war as a right for all children as well as a need that must be met. Such arguments, following Sommers have 'tugged more at the heartstrings than the purse strings of major international donors' ([46] p. 24). While USAID supports basic education, other international donors have been preoccupied with the misplaced view that education is a luxury in emergencies and not a humanitarian need ([47] p. 9). As a collective responsibility, the provision of education to all children despite prevailing conditions calls for coordinated efforts and actions even in situations where international NGOs do not normally work [46]. One of the ingredients that ignited war in Sudan was the marginalisation and exclusion of South Sudanese through the education system, which eventually led to deep differences in political and economic relations between North and South Sudan. Education promotes global human values and citizenship both in peace time and during civil wars.

The dark cloud of interethnic conflicts in the history 
of South Sudan suggests that peace accords that do not target the structural causes of conflict-exclusion from social welfare services, domination or suppression of ethnic identities, centre-periphery inequality, conflict over resources, intra-elite competition and brute causes or criminality risk- relapsing into a cycle of violence [48]. If accountable institutions are not in place to guarantee immediate socio-political inclusion, social welfare and economic equity for the majority of her citizens, a country risks not attaining durable or civil peace but an unstable institutional and constitutional peace.

\section{International Intervention and the Quest for Durable Peace}

The historical causes of conflict in South Sudan (categorized as 'new war') may seem intractable [34] but the internal causes of regular post-settlement violence suggest that statebuilding priorities retain ma- jor elements of the structure of political power that undergird the historical past of the RSS [49]. In prioritizing this statebuilding, the LPPs in the RSS are undermining durable peace in the country.Schomerous and Allen's incisive review of the LPP in the RSS reached the same conclusion ([30] p. 10). International peacebuilders use the orthodoxy approach of the LPP: prioritizing internationalization of the RSS by habituating new political norms that tend to reflect conditions and benchmarks of global governance institutions, promoting values like accountability, transparency, separation of powers and elections. To sustain liberal peace in the RSS, however, the National Democratic Institute (NDI) recommend that these interventions would have to consider concomitantly more emphasis on "better access to services that leads to improvements on the quality of life and guarantee peace dividends" to marginalized and politically excluded groups ([50] p. 71).

Table 1. Key areas of conflict addressed by international interventions.

\begin{tabular}{llll}
\hline $\begin{array}{l}\text { Reform of justice and } \\
\text { security institutions }\end{array}$ & $\begin{array}{l}\text { Culture of justice, truth } \\
\text { and reconciliation }\end{array}$ & Good governance & $\begin{array}{l}\text { Socioeconomic } \\
\text { development }\end{array}$ \\
\hline $\begin{array}{l}\text { Reintegration of } \\
\text { demobilised soldiers is } \\
\text { insufficient }\end{array}$ & $\begin{array}{l}\text { Uncertainty about the } \\
\text { future and false } \\
\text { expectations }\end{array}$ & $\begin{array}{l}\text { North/South disparities, } \\
\text { and intra-South } \\
\text { marginalisation }\end{array}$ & $\begin{array}{l}\text { Status of the Three } \\
\text { Areas. International } \\
\text { attention diverted from } \\
\text { the Three Areas. }\end{array}$ \\
$\begin{array}{llll}\text { Undeveloped police and } \\
\text { justice systems }\end{array}$ & $\begin{array}{l}\text { Hardening of ethnic } \\
\text { identities }\end{array}$ & $\begin{array}{l}\text { Tensions around } \\
\text { centralisation and weak } \\
\text { structures at State levels }\end{array}$ & $\begin{array}{l}\text { Migration of armed } \\
\text { pastoralists (this has not } \\
\text { featured in 2005); } \\
\text { discontented and under- } \\
\text { employed youth }\end{array}$ \\
\hline $\begin{array}{l}\text { Incomplete disarmament } \\
\text { among the population }\end{array}$ & $\begin{array}{l}\text { Unresolved issues of } \\
\text { access to natural } \\
\text { resources }\end{array}$ & Lack of representation & $\begin{array}{l}\text { Returnees want access to } \\
\text { resources. Return } \\
\text { destabilies communities }\end{array}$ \\
\hline
\end{tabular}

Source: ([51] p. 43).

Table 1 shows the orthodox approaches of multilateral interventions like the UN and bilateral (largely, the US) promotion of liberal peace. The bolded areas of intervention in post conflict Sudan are indicated on the figure including the following: reintegration of soldiers, development of police and justice systems, addressing tensions around centralization/weak state structures and the reintegration of returning refugees do dominate the LPP in the RSS. However, these peacebuilding endeavour must be pursued at the same time with felt needs of the local communities if peace is to be sustained. By comparing what international peacebuilders pursue, what the Government of the RSS pursues and the funding priorities of the main actors of peacebuilding, we discover a gap between the international objectives of legitimating the new state and the actual local needs for sustainable peace. As Roland Paris rightly warns, while "immediate democratization and marketization" (stable market democracies) of warshattered states is good wisdom, hastily resorting to this process is likely to be counterproductive: "market democracy is not the miracle cure for internal conflict". Political and economic liberalization is an inherently unsettling process. It can instead aggravate social tensions and undermine the prospects for stable peace in the fragile post-war conditions typical of countries just emerging from civil war. Good wisdom dictates that post-conflict peacebuilding begins with the establishment of a network of domestic institutions that are capable of dealing with the unfettered effects of democratization and marketization, as well as the gradual phasing in of political and economic reforms at the appropriate time. For this to be effective, peacebuilders must refrain from the unrealistic view that war-torn states can be rehabilitated over night ([29] p. 14). 


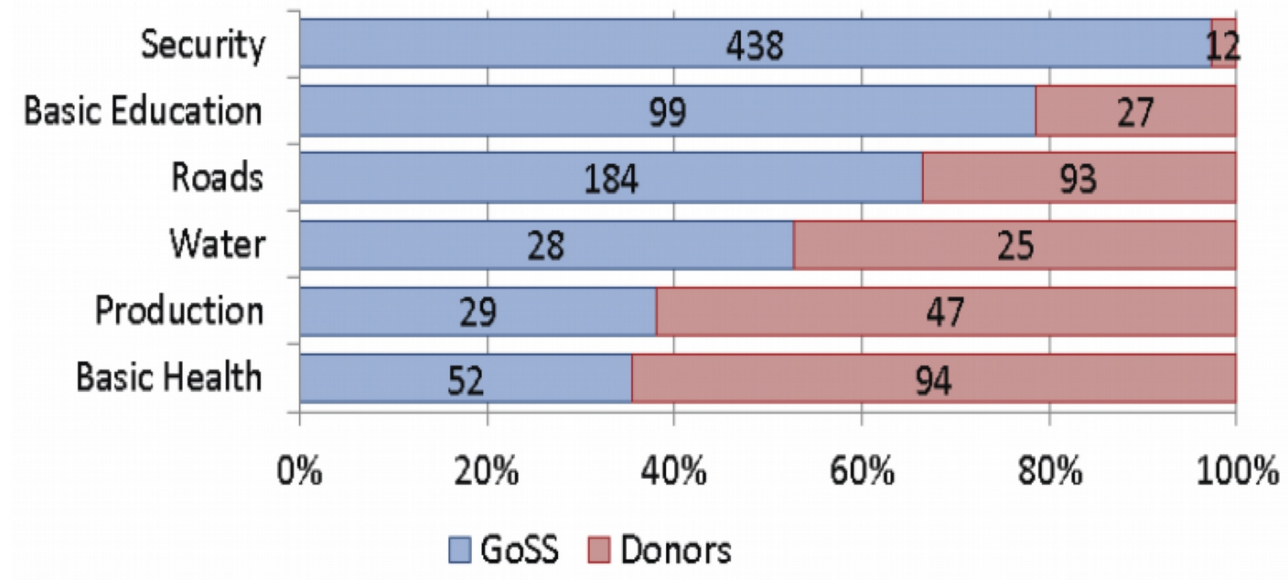

Figure 1. Funding priorities of the RSS (GoSS) versus funding priorities of international peacebuilders. Source: ([51] p. 3).

Figure 1 shows how peacebuilding funding to some basic services such as water and education easily elude international intervention in post conflict Sudan, despite the felt local need of access to these services. When this figure is cast against the wider Government of South Sudan (2010) budget, security accounts for $35 \%$ of the country's expenditure, basic services like health and education account for $7 \%$ and $4 \%$ respectively and rural development accounts for $3.4 \%$ of the budget [18]. From the perspective of the emancipatory approach to liberal peace, the RSS was increasingly being set for relapse into violence because of the lack of peace dividends and adequate social welfare among marginalized and rural communities emerging from conflict. Returnees expected better levels of services, non discrimination along tribal lines (or Dinka domination) and deconcentration of development in Juba. Without these, and as predicted by Afrobarometer [51], the local masses have been constantly anticipating violence. Politicians have continued to develop power bases centered on ethnic identity which eventuated into the crumbling of the current existing negative peace as of 15 December 2013.

International intervention into peacebuilding in Sudan has largely been a top-down process aimed at replicating westernity without regard to local context. The current LPP approaches highly prioritize centralized urban political institutions over heterogeneous local needs and preferences, which retard the bringing about of peace that the citizenry wish for themselves leading to authoritarian peace that narrows down political participation of citizens in elections. To guarantee durable civil peace in the RSS, Oliver Richmond suggest that orthodox peacebuilding must depart from the LPP and focus on "how one can move beyond hegemonic, authoritarian peace towards an everyday notion of peace sensitized to the local as well as the state and the global... and resting on a just social order and solidarity" ([40] p. 109).

\section{The Local Context of Social Welfare Exclusion and the LPP in South Sudan}

Afrobarometer's survey on what legitimizes a democratic society showed that $89 \%$ of respondents pointed to basic needs provision (water, food and shelter) while $75 \%$ want "democracy to deliver ... education, ... more strongly ... they insist on regular elections, majority rule, competing political parties or freedom to criticize the government" ([52] p. 2). Similarly, a survey of Southern Sudan by the NDI reported that the move for secession from Sudan is "to avert domination of Arabs ... and ... that independent Southern Sudan will be more prosperous" ([53] p. 7). This implies that the fragility of the democratic institutions in the RSS that translates into frail liberal peace is wanting from the perspective of delivering immediate improvements in the socio-economic sphere.

Afrobarometer's survey of nineteen African states undergoing peacebuilding in 2008 , found out that $66 \%$ of the populace saw their government's economic policies as not benefiting, but instead worsening the standards of living of the poor. Also, $50 \%$ of survey respondents opined that their local government institutions were illegitimate, using revenues for private gain rather than providing public services [54]. This suggests that in a country recovering from conflict like the RSS, the attainment of durable peace can tend to be fragile.

In a bid to graduate from an orthodox to an emancipatory approach that leads to durable peace in the LPP, it has been suggested that governments that have weak institutions must concentrate on providing public services such as security in poor neighbourhoods and in local markets. Also, the government in such a situation should concomitantly assess what needs constitute, as well as what local populations' perception of peace dividends is [55]. This implies that international intervention in South Sudan's LPP would best yield 
durable peace if it supports the country to efficiently respond to services needed by the most vulnerable of the local masses in the short and long term.

A foreign peacebuilding actor in the RSS conducted a survey using 67 focused group discussion sessions and a sample of 700 persons representative of all states, locations, tribes, religions, genders and age groups from March to June 2011 on two issues: Firstly, on the preference of the local masses as to the anchor of peacebuilding among Democracy, Development or both. Secondly, on what democratization agenda should be pursued in peacebuilding. Participants overwhelmingly $(59.1 \%)$ preferred that in peacebuilding, development (well being, improved standards of living) should precede democracy (elections); $37.7 \%$ preferred democracy to development whereas $3.2 \%$ preferred that both democracy and development be pursued simultaneously in the LPP. While those who preferred development thought of democracy as politics and an urban affair, those who believed in democracy defined it in terms of the socio-economic dividends it may offer in post-conflict times [56]. This resonates with the view that the narrow definition and support for liberal peace by the international community in line "with the over- arching neoliberal economic paradigm and failure to embrace an inclusivist approach to peacebuilding" works against "effective reconstruction, growth and development" ([57] p. 192). A primary-school-educated, Christian male in Juba for example, said "with democracy, government will hear the cry of the people and then bring development." Democracy was further thought of as a way to handle tribalism, nepotism and corruption that make public service institutions inefficient and ineffective ([58] p. 15). The Second survey question on which priorities public services must focus on in peacebuilding showed that: as a first, second and third preference for peace dividend, education constitutes $24.9 \%, 32.8 \%$ and $21.8 \%$ of the whole sample surveyed. In general, access to education is the second significant measure of expected peace dividend in the RSS. It is only second to access to water as the first, chosen by $27.5 \%, 14.6 \%$ and $19.5 \%$ of the survey respondents as their first, second and third preference in public service provision if the LPP in is to yield durable peace. In general, healthcare provisioning features as the third public service provision that should underpin durable peace in the country.

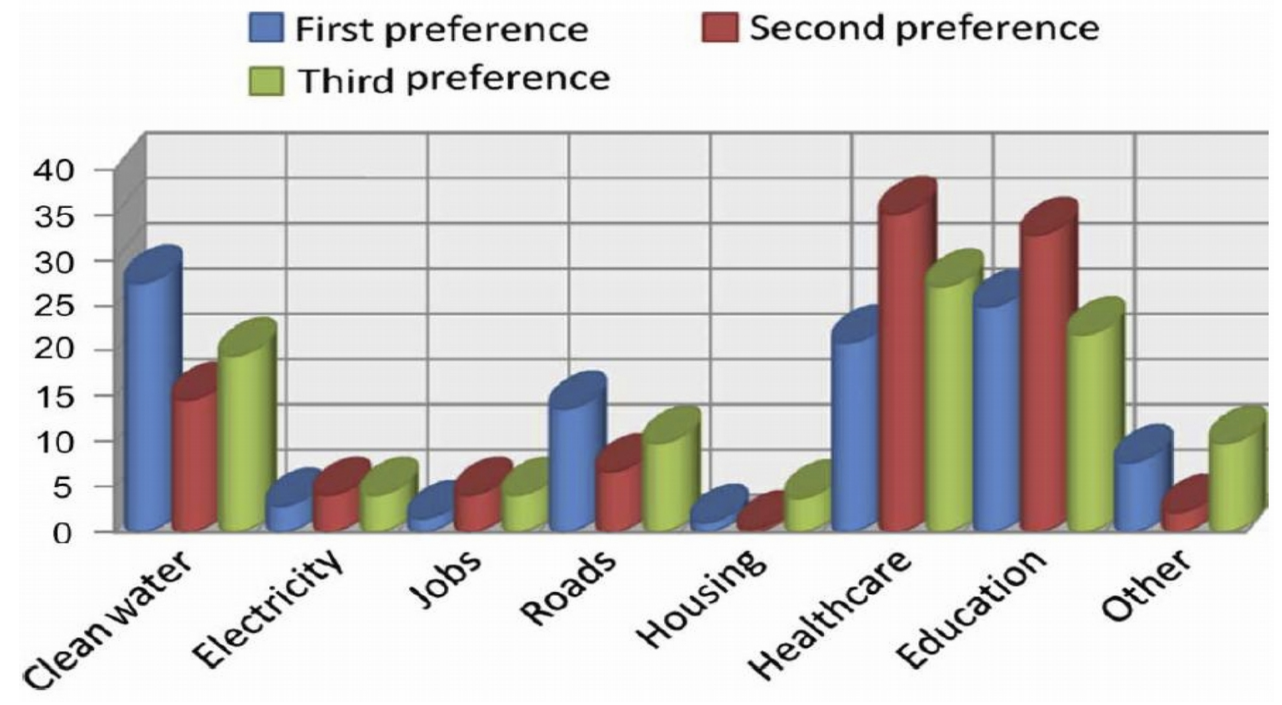

Figure 2. Local preferences for peace dividends in the RSS.

Source: ([57] p. 17).

The data presented in figure 2 above corroborate a joint survey of the RSS by the London School of Economics (LSE) and the Partners Achieving Change together (PACT) -a development organization. The LSE/PACT study concluded that better access to social services guaranteed through infrastructural development and improved quality of life would be the most remarkable aspects of any durable peace in South Sudan [30]. But how should social welfare be initiated and sustained for South Sudan's most venerable groups? A religious leader in Raja County, South Sudan puts it thus: "information and knowledge is desperately needed for us to become informed citizens" ([30] p. 71). This is because as argued below, education does not only improve the quality of civic engagement but also the quality of life for the educated and of the community in which he or she lives as a whole.

\section{Formal Education and Liberal Peace in South Sudan}

Formal schooling and training in conflict transformation sensitizes a society to the inequities of the system to facilitate intergroup dialogue, healing and reconciliation, and nurturing the idea or capacity for peace through integrated schools having curricula related to community relations, vocational training and 
community development at primary and post primary vocational levels [41]. The need for education to help citizens to contribute to quality participatory governance has been avidly expressed in South Sudan [30]. It has been made clear that restricted access to education or an inappropriate curriculum such as the Arabization or Islamization of Southern Sudanese schools $[4,8-9,11]$, has led to the deterioration of interethnic relations [42], created an unskilled, corrupt, and Dinka dominated civil service [18], making liberal peace unstable in the country. Although the United Nation's International Children's Emergency Fund's (UNICEF) current Peace Education initiative in South Sudan organizes workshops in mediation, negotiation, conflict management and non-competitive dialogue, it is a topdown process that helps in resolving immediate and proximate causes of violence and not the structural causes in rather abstract ways [42].

Peacebuilding education should rather be a bottomup process in which pupils of primary school age are incentivized (through provision of meals at school, for instance) to keep them at school, where they will be reoriented to attitudes of peace. In a limited top-down process, international peacebuilders should support the RSS to build primary schools and post-primary schools, teacher training colleges and vocational institutions so as to support durable peace. It is a process founded on the experiences and opportunities to augment the capacity for wellbeing among a highly unskilled and unemployed South Sudanese youth by providing them with immediate and relevant vocational training that facilitates entrepreneurship, trade and higher incomes that incentivize them to avert proclivity to war. As an indispensable factor, peacebuilding education should be immediately incorporated into current orthodox democratization and free market institutionalization of the current LPP in Sudan in order to actualize the emancipatory approach to the LPP that results in durable civil peace.

\section{Access to Primary Education and the Durability of Liberal Peace}

After the CPA the number of pupils enrolled in primary school increased from about 700 '000 to 1.6 million. However, the the RSS does not yet have the capacity to keep up with the demand for education. Additionally, donor support for education remains highly insufficient through reconstruction programmes in the country [58]. UNICEF estimates that in Sudan $70 \%$ of children aged between 6 and 17 have never been to school, 1 out of 10 pupils complete primary school and less than $2 \%$ of the population have completed primary schooling [58]. Worse still, a 2009 assessment revealed that $96 \%$ of all teachers in South Sudan have no formal training [59]. The lack of access to education is captured in figure 3 below in which school pupils in Yei, Jonlei state are seen sitting on makeshift benches under a tree.

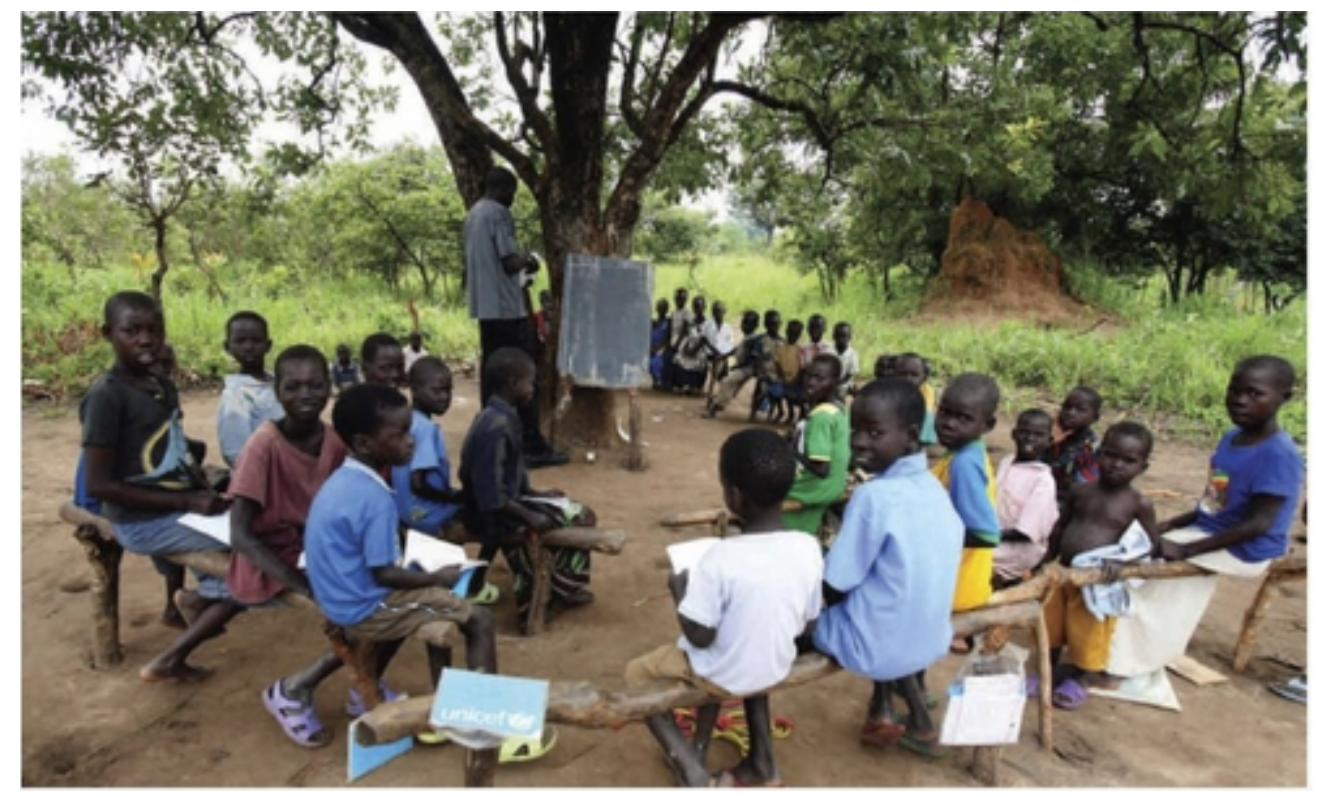

Figure 3. Pupils studying under a tree.

The picture above tells the tragic story of the acute lack of space for teachers and classrooms for learning. Wandera, an adult learner in Kuol, South Sudan who thinks that education will preclude war in the country asserts that: "Education is very, very important for peace. If you are educated you will be able to know what peace is, you will be able to educate people about reconciliation, forgiveness and coming together to solve problems". While equating education to peace, respondents were unanimous that "an educated individual will be able to think and act well, put his or her education to good use for development and will have an open-mind" (Jacob, Interview, Dengnhial, 11 May 2013). According to the North-South Institute, 
a combination of peace, civic and citizenship education will instill a sense of responsible citizenship that "fosters a culture of peace and peacebuilding through conflict mitigation, resolution and reconciliation. Civic education seeks to build an understanding of the democratic system based on notions of civic and human rights. Citizenship education attempts to teach an awareness of rights and responsibilities and instill respect for others' rights and viewpoints" ([60] p. 1). Figure 4 below shows Dengnhial primary school pupils appealing to the SPLM/A to turn war policies into development projects.

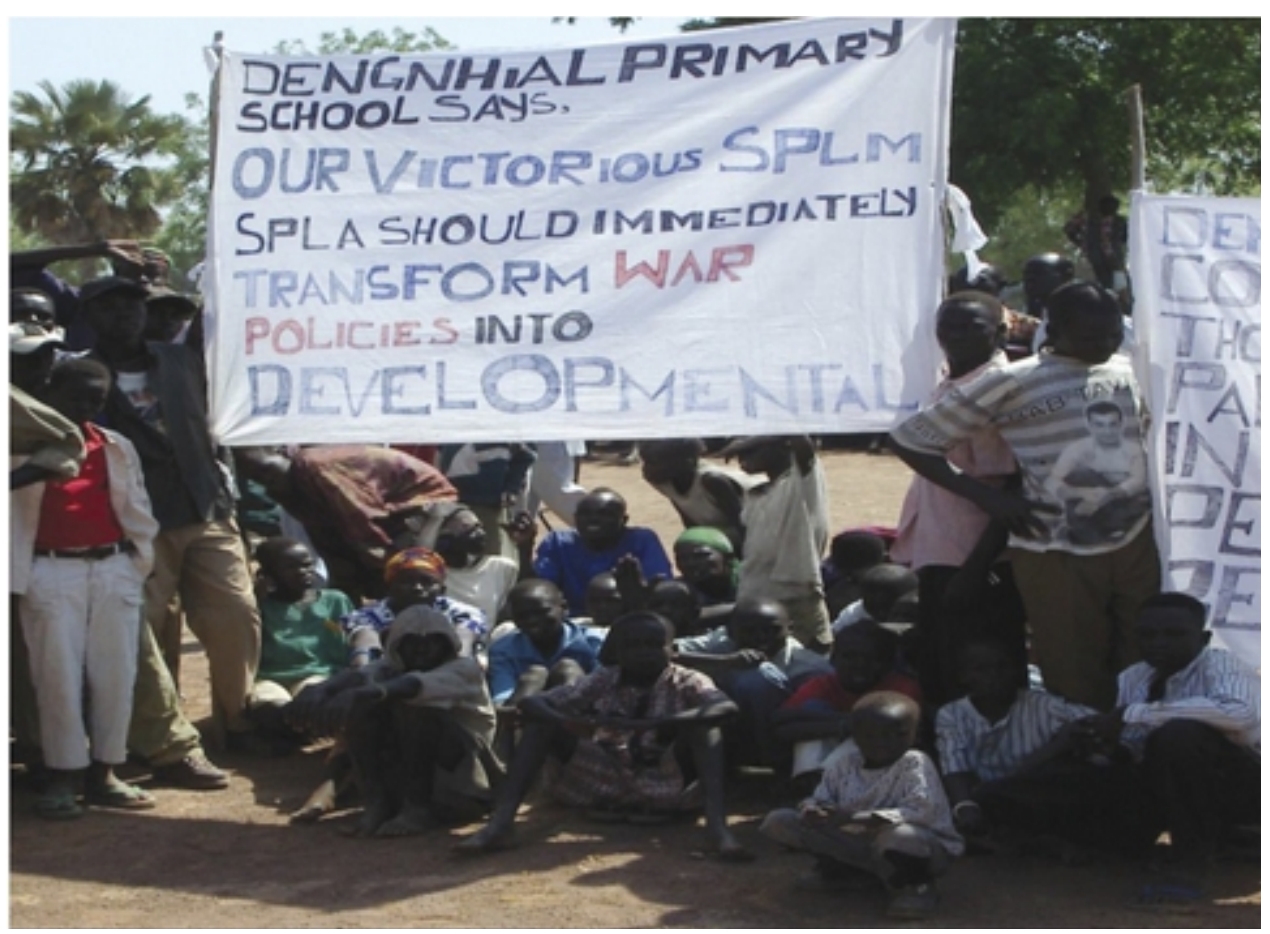

Figure 4. Calls for the transformation of war policies into development policies.

Reychler Luc holds that formal education facilitates sustainable peace in three ways that are relevant to the South Sudanese context, if the curricula are designed to foster community relations and community development [42]. Firstly, primary education would be a forum for effective interethnic communication. Considering that about 66 ethnic languages are spoken in South Sudan [26], the use of English as a common language will serve as a good medium for fostering and nurturing interethnic communication. Secondly, it helps dismantle sentimental walls related to perceived domination by the Dinka or other forms of groupings such as the SPLM. Increased access to primary schooling takes away despair from victims of social exclusion because it nurtures individuals with requisite skills for future political participation and in the long run, solves political tensions. Hannah Bol, in Kuol, asserted that "Now that schools have been opened, everyone has seen that education is important and that they need to come, and that war and guns are not the future!" [26]. Thirdly, formal primary schooling in integrated schools promotes an integrative political climate [42]. The government of the RSS currently runs on the basis of exclusive circles of patronage and marginalization [46]. Participation in governance would therefore, become skill-based with the introduction of formal education.

\section{Vocational Education, Peace Dividends and the Durability of Liberal Peace}

This study has established that there is a strong correlation, almost a favourable causal link between the provision of peace dividends (schooling, health services, jobs, higher living standards, social development) and the durability of peace. "The lack of livelihoods opportunities for youth and the potential for creating and exacerbating tensions and relapse to violence" in post war states has also been noted ([49] p. XVII). This has been recorded especially in Lakes, Warrap, Jonglei and Upper Nile States, which are the most conflict-affected regions in South Sudan. In the survey conducted by the NDI on what locals in South Sudan preferred as peace dividends, some said "If we are educated...we would not so much think of government to do for us everything;" "we would create our own project and work on our own roads but we do not have the skills so we really need education to be the priority here" ([60] p. 9). One respondent told us that "Giving us education is like teaching us how to fish, and help ourselves instead of perpetually depending on others" (Joseph, Jonglei, interview of 20 May 2013).

This suggests that for international peace building interventions to solidify peace, the RSS must be sup- 
ported to create an enabling environment for young people's livelihoods and/or employment [62]. Considering the very low literacy levels in South Sudan, the setting up of rural craft schools in carpentry, masonry, pottery, and agriculture and institutes for electricity and electronics, maintenance, production engineering, dress making, nursing, clerical studies are necessary if durable peace is to be attained. For our intent, vocational studies help academically less able students, instilling technological knowledge related to some particular function, craft and trade [62]. The following figure is a framework showing how vocational education can bring about peace dividends to sustain peace.

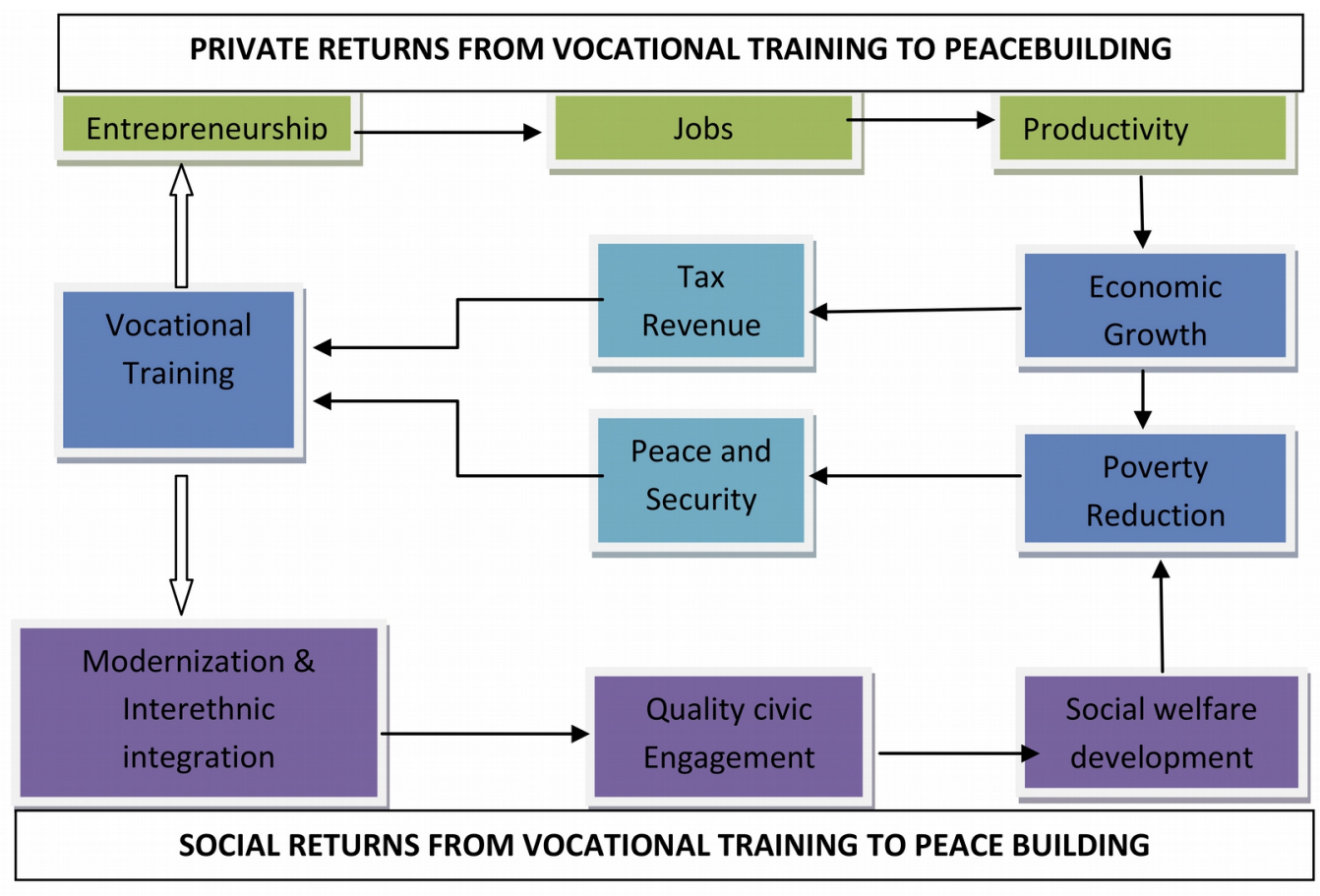

Figure 5. The links between vocational training and peace dividends.

In the past, vocational training has been criticized as a financially costly policy to implement, being of lower value to academic or general education in terms of the low income it attracts and the false probability that it can guarantee quicker employment [62]. Nowadays, vocational education is seen as training that facilitates the acquisition of specific vocational skills for a lifetime that would manifest in entrepreneurship, poverty reduction and the integration of idling young people [in South Sudan] into the working world of the informal or private sector $[63,64]$.

In practice, vocational education would train the workforce for self-employment and raise the productivity of the informal sector [63]. The availability of skills would attract more foreign direct investments, modernizing South Sudan and promoting heterogeneous communities that facilitate interethnic integration.Vocational training is analogous to some form of social engineering: transforming unemployed youth to find employment, providing poor segments in society with a rising income and improved living standards and supplying to a community emerging from the destruction of war, middle level technicians such as, nurses, midwives, plumbers and brick layers [61]. This is why vocational education is considered socially useful work, which would help citizens develop stronger awareness of the contribution of their work to the wellbeing of society [62]. When social welfare development for all is triggered through the extension of access to formal schooling, the democratization and institutionalization of the free market that yield fragile authoritarian peace, constitutional peace and institutional peace graduate into an emancipatory approach that addresses social injustices to yield durable civic peace.

\section{Conclusion}

This study has found that the deeply rooted causes of relapse to violence in South Sudan are historically situated on ethnic segregation orchestrated by the Anglo-Egyptian rule of the then Southern Sudan. This dual rule left the area bereft of public goods, social welfare institutions or solid economic development outcomes. This segregation extended to political exclusion as at independence, of more than 900 positions of postcolonial administration, people from the three states of southern Sudan only got appointed into 8 [21].

Shortly, after independence, restricted access to social welfare, especially formal education informed ethnic domination over or the exclusion of Southern Sudanese in the realm of political participation. Consequently, the incomprehensible nature of the CPA that legitimized the Dinka's domination of the SPLM/A government caused the exclusion of significant local 
actors from the peace deal. Subsequent political participation has further undermined the search for durable peace. Because most of the liberal peace building in independent South Sudan fails to implement projects that simultaneously strengthen democratic institutions as well as addressing the deep rooted causes of relapse to conflict, for example the lack of social welfare institutions that should lead to peace dividends, the liberal peace that is this far instituted or constituted is indeed, fragile.

Surveys conducted by Afrobarometer [52] and the NDI [60] indicating local preference for the immediate delivery of formal education, health and other basic needs (clean water) over democratization, suggest that the Liberal Peace Export to South Sudan is divorced from local context, making the transposition of liberal peace projects ineffective and making liberal peace fragile in the country. This asymmetry of information on what constitutes need for durable peace between international peacebuilders (principal) and the South Sudanese citizens and locals (agent) has exacerbated ethnic marginalization and made the institutional installations of the LPP faulty. This dovetails with the failure of neoliberal peace project in post-conflict Sierra Leone [56].

The issue of marginalization translates to lack of services (like water, health and education) against areas/peoples in the Jonglei and Blue Nile states. These areas are also lagging behind in terms of representation in political structures. The role of the State in regulating such disparities has been minimal or even negative. It operates on the basis of exclusive circles of patronage and marginalization. Marginalization plays out as the stick and patronage as the carrot within the context of social welfare exclusion and inclusion among different ethnic groups [45]. Although the emancipatory approach is considered impractical in the LPP, this research recommends the provision of primary education and post-primary vocational education as a policy implementation path to actualize the emancipatory approach to the LPP in South Sudan.

\section{References}

[1] Butros BG. An Agenda for Peace: Preventive Diplomacy, Peacemaking and Peacekeeping. Report of the Secretary General at the summit meeting of the Security Council. 31 January 1992. New York, NY, USA: United Nations; 1992.

[2] Young T. A Project to be Realised: Global Liberalism and Contemporary Africa. Millennium: Journal of International Studies. 1994;24(3):527-546.

[3] Collier P. Economic Causes of Civil Conflict and their implications for Policy. Mimeo, Washington, DC, USA: World Bank; 2000.

[4] Jeffrey G. Chronology of the Important Events in South Sudan. 2011. Available from: http://www. southsudannation.com/chronology/.
A low level of female education in the RSS translates into the inability to control birth rates, implying continuous growth in population and insufficient consumption. Many households in the RSS are already "living on a sub-sustainable level, due in part to an uneven distribution of resources, but also because in many regions (...) population has outgrown essential resources". Among various methods identified by the United Nations International Conference on Population and Development (ICPD), September 1994, Cairo, Egypt, and applicable to the RSS are the: (1) empowerment of women and girls in the economic, political and social spheres (2) removal of gender inequalities in education and (3) integration of family planning in synergy with other efforts to improve mother and child health [64]. Poverty is perpetuated and exacerbated by poor maternal health, gender discrimination and lack of access to birth control. This calls for the need to prioritize the advancement of human development for women and for all victims affected by violence and insecurity as well as the creation and implementation of a national strategy for human development so as to support peacebuilding and its sustainability, advance the human development process, enhance the needs of children, the elderly and all victims of conflict ([27] p. 6). Research evidence suggest an inverse relationship between levels of female education, and birth rate: an educated woman is more likely to make better use of existing health care services for both preventive and curative health services, "to accept medical advice and to make timely recourse to modern health care facilities, greater identification with the outside world, more social confidence at handling officials and willingness to go out of the home for services" ([65] p. 20, [66]).

Additionally, sustainable environmental governance will mitigate the impact of climate change and permit the government to cope with increasing pressure on natural resources so as to ensure a sustainable future for current and returning populations.

[5] McEwan JP. Private Costs and the Rate of Return to Primary Education. Applied Economics Letters. 1999;6(1):759-760.

[6] Bloom DE, Hartley M, Rosovsky H. Beyond Private Gain: The Public Benefits of Higher Education. In: Forest JJF, Altbach GP, editors. International Handbook of Higher Education. Dordrecht, The Netherlands: Springer; 2007. pp. 293-308.

[7] Richmond OP. The Problem of Peace: Understanding the 'Liberal Peace'. Conflict, Security \& Development. 2006;6(3):291-314.

[8] Deng LB. Education in Southern Sudan: War, Status and Challenges of Achieving Education for All Goals. Respect, Sudanese Journal for Human Rights Culture and Issues of Cultural diversity. 2006;4(4):1-27.

[9] Deng LB. The Curse of Mineral Resources: 
The case of revenue sharing arrangements in Sudan. Consultation Report 4. Cambridge, UK: African Renaissance Institute (ARI) \& Relationships Foundation International (RFI); 2002.

[10] Deng FM. War of Visions: Conflict of Identities in the Sudan. Washington, DC, USA: Brookings Institution; 1995.

[11] Lesch A. Sudan Contested National Identities. Oxford, UK: James Currey; 1998.

[12] Richardson P. Avoiding War in South Sudan. Africa Policy Watch. 2011;7(6):759-760.

[13] Mckulka T. Audio Slideshow: Across the two Sudans. Available from: http://www.bbc.co.uk/ news/world-africa-17339798.

[14] The Republic of South Sudan. The Household Health Survey. 2006. Available from: http://www.bsfsouth-sudan.org/sites/default/files/SHHS.pdf.

[15] South Sudan Centre for Census Statistics and Evaluation (SSCCSE). Poverty in South Sudan: Estimates from National Baseline Household Survey (NBHS). 2009. Juba, South Sudan: Southern Sudan Center for Census Statistics and Evaluation; 2010.

[16] Okwaroh K. South Sudan: Resources for Poverty Eradication: A background Paper. Development Initiatives: Africa Hub. 2012. Available from: http://d evinit.org/wp-content/uploads/2013/08/South-Sudanbriefing1.pdf.

[17] House of Commons, International Development Committee. South Sudan: Prospects for Peace and Development. 2012. Availaible from: www.parliament.uk/indcom.

[18] Gettleman J. After Years of Struggle, South Sudan Becomes a New Nation. New York, NY, USA: New York Times, 9 July 2011.

[19] UNICEF/OLS. School Baseline Assessment Report for Sudan, Nairobi, Kenya. UNICEF; 2002.

[20] Government of South Sudan (GoSS). South Sudan Development Plan: 2011-2013. Juba, South Sudan: Government of South Sudan; 2011.

[21] GoSS and United Nations Development Programme (UNDP). Environmental Impacts, Risks and Opportunities Assessment: Natural Resources Management and Climate Change in South Sudan. Juba, South Sudan: UNDP; 2011.

[22] Pemunta NV. The impact of climate change on food security and health in Northern Cameroon. In: Keynes CB, Lucero O, editors. New Developments in Global Climate Warming Research: Climate Change and its Causes, Effects and Prediction. New York, NY, USA: Nova Publishers; 2013. pp. 1-50.

[23] Zakieldeen SA. Adaptation to Climate Change: A Vulnerability Assessment for Sudan. Gatekeeper Series. 2009. Available from: http://dlc.dlib.indiana. edu/dlc/bitstream/handle/10535/5850/14855IIED.pdf ?sequence $=1$.

[24] Calderone M, Maystadt JF, You L. Local warming and Violent Conflict in North and South Sudan. IFPRI Discussion Paper No. 01276. 2013. Available from: http://www.ifpri.org/sites/default/ files/publications/ifpridp01276.pdf.

[25] IRIN humanitarian news and analysis. Analysis: South Sudan struggles to meet demand for education. Available from: http://www.irinnews.org/ report/96237/analysis-south-sudan-struggles-to-meetdemand-for-education.

[26] UNDP. Sudan National Human Development Report 2012. Geography of Peace: Putting Human Development at the Centre of Peace in Sudan. Khartoum, Sudan: UNDP; 2012.

[27] United Nations Development Programme. (UNDP). Human Development Report 2013. The Rise of the South: Human Progress in a Diverse World. New York, NY, USA: United Nations Development Programme; 2013.

[28] Paris R. Saving liberal peace. Review of International Studies. 2010;36(1):337-365.

[29] Schomerus M, Allen T. South Sudan at odds with itself: Dynamics of conflict and predicaments of peace. London, UK: Development Studies Institute; 2010.

[30] Richmond PO. Becoming Liberal, Unbecoming Liberalism: Liberal-Local Hybridity via the Everyday as a Response to the Paradoxes of Liberal Peacebuilding. Journal of Intervention and Statebuilding. 2009;3(3):303-323.

[31] Ylönen A. Limits of 'Peace through Statebuilding' in Southern Sudan: Challenges to State Legitimacy, Governance and Economic Development during the CPA Implementation, 2005-2011. Journal of Conflictology. 2012;3(2):28-40. Campus for Peace, UOC. Available from: http://journal-of-conflict ology.uoc.edu/index.php/journal-of-conflictology/arti cle/view/1513.

[32] Barth K, Douma P, van Laar S. The struggle after combat-The Role of NGOs in DDR Processes: Synthesis Study. The Hague, The Netherlands: Cordaid; 2008.

[33] Kaldor M. In Defense of New Wars. International Journal of Security and Development. 2013;2(1):1-16.

[34] Richmond PO. Critical Research Agendas for Peace: The Missing Link in the Study of International Relations. Alternatives: Global, Local, Political. 2007; 32(2):247-274.

[35] Chandler D. The uncritical critique of 'liberal' peace. Review of International Studies. 2010;32(3): 475-494.

[36] Keith K, Jütersonke O. Peace, Security and Development in Post-conflict environments. Security Dialogue. 2005;36(4):429-446.

[37] Paris R, Sisk TD. Introduction: Understanding the contradictions of postwar statebuilding. In: Paris R, Sisk TD, editors. The Dilemmas of Statebuilding. London, UK and New York, NY, USA: Routledge; 2009. pp. 1-20.

[38] Luckham R. Democracy and Security: A shotgun Marriage? Global Consortium on Security Transformation. Working Paper No. 8. 2009. 
[39] Richmond PO. Peace in International Relations. London, UK: Routledge; 2008.

[40] Bush D, Kenneth D, Saltereli D, editors. The Two Faces of Education in Ethnic Conflict: Towards a Peacebuilding Education for Children. Florence, Italy: UNICEF Innocenti Research Centre; 2000.

[41] Luc R. From Conflict to Sustainable Peacebuilding: Conceptual Framework. In: Peacebuilding: A Field Guide. London, UK: Lynne Rienner Publications. Inc.: 2001. pp. 3-16.

[42] Postman N. The End of Education: Redefining the Value of School. New York, NY, USA: Vintage Books; 1996.

[43] Psacharopoulos G. Returns to Investment in Education: A Global Update. World Development. 1994;22(9):1325-1343.

[44] Attree L. The peacebuilding potential of fragility assessments. 2012. Available from: http:// www.oecd.org/site/dacpbsbdialogue/documentupload/ 49151944.pdf.

[45] Sommers M. Children, Education and war: reaching education for all (EFA) objectives in countries affected by Conflict. CPR Working Paper No.1. World Bank: Conflict Prevention and Reconstruction Unit; 2002.

[46] Sinclair M. Education in Emergencies. In: Crisp J, Christopher T, Diana, C, editors. Learning for a future: Refugee Education in Developing Countries. Geneva, Switzerland: UNHCR; 2001. pp. 1-83.

[47] De Waal A. Sudan: What Kind of State? What kind of crisis? Occasional paper no. 2. London, UK: Crisis States Research Centre, LSE Press; 2007.

[48] Barnett M. Building a Republican Peace: Stabilizing States after War. International Security. 2006;30(4):87-112.

[49] Paris R. At War's End: Building Peace After Civil Conflict. Cambridge, UK and New York, NY, USA: Cambridge University Press; 2004.

[50] GoSS. Donor Book 2010. Juba, South Sudan: Government of Southern Sudan; 2010.

[51] Afrobarometer. Afrobarometer Briefing Paper No. 1. 2002. Available from: http://www.afrobaro meter.org/afrobriefNo1.pdf.

[52] Levy LA, Cook DT. Citizen Expectation, Aspiration and Concerns about Referendum and Beyond. 2010. Available from: http://www.ndi.org/ files/Southern_Sudan_at_the_Crossroads.pdf.

[53] Little $\bar{E}$, Logan $\bar{C}$. The Quality of Democracy and Governance in Africa. New Results from Afrobarometer Round 4. A Compendium of Public Opinion Findings from 19 African Countries. 2008.
Available from: http://www.afrobarometer.org/ files/documents/working_papers/AfropaperNo108.pdf.

[54] Grindle SM. Good Enough Governance: Poverty Reduction and Reform in Developing Countries. Governance. 2004;17(4):525-548.

[55] The raw data of this survey is available for reference at the website http://www.popular peace.org/\#!research_data/c96h.

[56] Pemunta NV. Neoliberal peace and the development deficit in post-conflict Sierra Leone. International Journal of Development Issues. 2012;11(3):192-207.

[57] Roberts D. Surveying South Sudan: The Liberal, the Local and the Legitimate. Journal of Intervention and Statebuilding. 2013;7(1):65-86.

[58] Hewison M. The Status of Teacher Professional Development in Southern Sudan. Washington, DC, USA: United States Agency for International Development; 2009.

[59] The North-South Institute. Educating for Peace in South Sudan. Policy Brief. 2012. Available from: http://reliefweb.int/sites/reliefweb.int/files/re sources/educating_for_peace_in_south_sudan_final.pdf.

[60] Levy AL, Cook TD. Southern Sudan at the Crossroads: Citizens' Expectations, Aspirations, and Concerns about the Referendum and Beyond. Wahington, DC, USA: National Democratic Institute (NDI); 2011.

[61] Psacharopoulos G. Vocational education and Training Today: Challenges and Responses. Journal of Vocational Education \& Training. 1997;49(3):385-393.

[62] Che MS. Technical and Vocational Education in Cameroon and Critical Avenues for Development. Research in Comparative and International Education. 2007;,2(4):333-345. Available from: http://dx.doi.org/ 10.2304/rcie.2007.2.4.333.

[63] Oketch OM. To vocationalise or not to vocationalise? Perspectives on current trends and issues in technical and vocational education and training (TVET) in Africa. International Journal of Educational Development. 2007;27(2):220-234.

[64] WOA! World Overpopulation Awardness. Available from: http://www.overpopulation.org/popsustainability.html.

[65] Pemunta NV, Fubah MA. Socio-Cultural Determinants of Infant Malnutrition in Cameroon. Journal of Biosocial Science. 2014:FirstView;1-26.

[66] Pemunta NV, Aristide AB. Socio-spatial occupation, conflict and humanitarian assistance for Bororo cross-border migrants in east Cameroon. International Journal of Development Issues. 2013;12(3):271-288. 
Appendix 1. List of Abbreviations.

CPA Comprehensive Peace Accord

DDR Disarmament, Demobilization and Reintegration

EFA Education for All

GDP Gross Domestic Product

GoSS Government of South Sudan

HDI Human Development Index

HIV Human immuno virus

ICPD International Conference on Population and Development

IFPRI International Food Policy Research Institute

IPC Integrated Food Security Phase Classification

LPP Liberal Peace Process

LSE London School of Economics

NDI National Democratic Institute

NGO Non-Governmental Organisation

PACT Partners Achieving Change together

RSS Republic of South Sudan

SSCCSE South Sudan Centre for Census Statistics and Evaluation

SPLM/A the Sudan People's Liberation Movement/Army

TVET Technical and Vocational Education and Training

UNHCR United Nations High Commissioner for Refugees

UN United Nations

US United States

UNICEF United Nations Children Emergency Fund

USAID United States Agency for International Development 